\title{
Poverty Alleviation and Women Empowerment through Tourism Development - an Explorative Study of Model Ventures
}

Priyakrushna Mohanty* and Anu Chandran $^{\dagger}$

\begin{abstract}
Although research on tourism, poverty alleviation and women empowerment are being carried out extensively, integrative studies linking all three aspects are scant. This paper is an attempt to bridge the existing gap in the literature by connecting the concepts of tourism-driven poverty alleviation and gender empowerment through tourism and feminization of poverty.
\end{abstract}

Keywords: Tourism, Poverty Alleviation, Women Empowerment, Feminization of Poverty, Sustainable Development, Gender

\section{Introduction}

The word Poverty derives its origin from the Latin word "paupertās" (derived from Latin word "pauper" meaning poor) and the old French word "poverté" (Skeat, 1980). The Oxford online dictionary defines poverty as "The state of being extremely poor". So far the most accepted definition for absolute poverty or destitution was coined in the United Nations Expert Group Meeting on Youth Development Indicators held in New York. It defined absolute poverty as: "a condition characterised by severe deprivation of basic human needs, including food, safe drinking water, sanitation facilities, health, shelter, education and

Pondicherry University, Pondicherry, India; pkmohanty90@gmail.com

† Pondicherry University, Pondicherry, India; anoos_ind@yahoo.co.in 
information. It depends not only on income but also on access to services." (Gordon, 2005).

However, Poverty is a multifaceted social phenomenon (Sen, 1997; Foster \& Sen, 1997; and Lipton \& Ravallion, 1995), and there is no single definite definition for the term (BBC-Poverty-Definitions, 2016). It can be noted from the definitions that poverty is not the mere economic inability to earn enough to meet someone's daily needs; it is about the inability to move up the social strata; it is about the lack of opportunity, and most importantly, it is about the lack of hope. Poverty is a chronic distress that has plagued many a region across the globe. As per World Bank estimates, in the year 2012, 896 million people, that is, about $12 \%$ of the world's population lives below the poverty line of $\$ 1.90$ a day. Sub-Saharan Africa (388.7 million) and Southern Asia (309 million) are home to $78 \%$ of the world's extreme poor (World Bank, 2013). The most alarming fact here is that despite the several measures taken both at the national and International level, absolute poverty (number of absolute poor) continues to remain the same.

Further, the issue of poverty is complex as there is no single cause or solution to it. Defining poverty and its causes varies substantially depending on different factors like age, gender, culture, income and other socio-economic variables. From these variables, gender inequality is considered to be one of the most important variables. Since the 1970s, there has been a growing consensus about the "feminization of poverty," i.e. the presence of more acute poverty among women than in their male counterparts. Diana Pearce, who coined the term "feminization of poverty", in her paper The Feminization of Poverty: Women, Work, and Welfare highlighted that women constituted two-thirds of the world's poor over the age of 16 (Pearce, 1978).

Consequently, there was a growing need to acknowledge gender issues in all spheres of poverty alleviation and development related issues. These concerns gave rise to the phase of gender and development era which was also christened as Women in Development (WID). However, WID considered women as vulnerable groups that needed help from the society to access the resources, as equally as men. The Marxist feminists criticized this very aspect in the later years. Hence owing to the criticisms, WID 
was then designated as Women and Development (WAD) and subsequently as Gender and Development (GAD) (Singh, 2007). Thus it is evident that poverty alleviation and gender equality are spokes of the same wheel. Hence, they cannot and shall not be dealt in isolation and these warrant an integrated approach.

The Millennium Development Goals (MDGs) was a structural action plan carried out by the UN to nurture systematic and sustainable development across the world. Formulated in the year 1990, MDGs was the result of intensive discussions, expert meetings, agreements and resolutions carried out by UN with various national and international organizations and institutions. The MDGs have embraced poverty alleviation and women empowerment as its Goal 1 and 3 respectively (McArthur, 2014). Even though much have been done since then in terms of intervention plans and structural policy making, poverty alleviation (Scheyvens, 2008) and women empowerment (UNDP, 2016) still remain far-fetched dreams.

Tourism is one of the fastest growing industries of the modern era contributing almost $10 \%$ to the global GDP. It is also a labourintensive industry that provides $3.6 \%$ of the world's employment directly and $9.6 \%$ in total, i.e. the sum of all direct, indirect and induced employment. It is one of the few industries in the whole world that has shown a higher proportion of growth in the developing or underdeveloped areas which constitutes the highest number of poor in the world (WTTC, 2015). Also, $60-70 \%$ of all the people who derive their jobs from tourism or allied activities are women (International Labor Organization, 2008). Thus, the tourism industry has earned a reputation of being an engine for gender equality and poverty alleviation.

Though research work on tourism, poverty alleviation and women empowerment are being carried out, studies linking all three aspects are scant. This paper attempts to bridge the prevailing gap in the current academic literature and build the theoretical constructs drawing from the tourism industry's potential to serve as a panacea to plug the problems related to poverty and gender inequality. The paper assimilates the leads and reflections highlighted in path-breaking academic works which are mostly scattered and provide some pragmatic dimensions. Certain case 
studies that underscore the initiatives in the realm of tourism for poverty alleviation and solution-driven approaches through women empowerment have been reviewed to portray the essence of such projects as having the capabilities to address the multifaceted issues of poverty. Moreover, reviews also point outto the intrinsic capabilities. Such projects act as solution driven approaches through women empowerment to offset the various problems prevailing especially in underdeveloped and developing regions. How far the linkages between tourism-poverty alleviation projects and women empowerment can complement sustainable development endeavours are examined in this work.

\section{Study Objectives}

The paper aims to bring out the conceptual academic and intellectual perspectives highlighting the triangular connect of tourism, poverty and gender-related agendas. Designed as an explorative study, the work tries to underscore the elementary dimensions of sustainability raised by various authors, practitioners, experts, consultants etc. that turns the spotlight on poverty litigation focusing on women empowerment. The paper also aims to draw attention to certain case studies that give thrust to the power of tourism in eliminating poverty and gender biases.

\section{Research Methodology}

The data for this study was compiled and organized mainly from a review of academic works, an archive of media reports, journals, and periodicals. Molded overall as a content analysis of academic works, the study lays accent on the case study approach analyzing the paradigms drawn from the literature in the identified model development initiatives globally that have in principle adopted the path of sustainable development through women empowerment in the tourism industry. Definitive points and commonalities were identified during the process, and a solution-driven recommendation approach was adopted to derive vital points from the crux of published literature that aid in addressing the gap areas, critical views, flaws, and deficiencies. 


\subsection{The Feminization of Poverty - A Critique}

During the 1970s, there was a progressive consensus across academicians, practitioners and various organizations that poverty among women is more prevalent than in men and these concerns called for studying poverty from the gender perspective (Whitehead, 2003, Zuckerman, 2001 and Chant, 2007). In this regard, many literatures were produced, and the most prominent and popular among them was Diana Pearce's (1978) work titled "The Feminization of Poverty: Women, Work, and Welfare". At the prelude of her paper, she mentions

"Poverty is rapidly becoming a female problem. Though many women have achieved economic Independence from their spouses by their participation in the labour force (and in some cases, by divorce), for many the price of that independence has been their pauperization and dependence on welfare,"

Much water has flown under the bridge since then, yet poverty among women remains a concern throughout many nations. This feminization of poverty can be best described by Cagatay's (1998) three ideas. Firstly, there is a higher incidence of poverty among women than men, i.e. poverty is more frequent and widespread among women than men. In his second idea Catagay notes, the severity of poverty among women is more than men, and finally, the incidence of poverty among women is increasing over time.

As per recent statistics by UN (2015), on an average 1 in every 3 women in developing countries have no say in the purchasing decisions of households, and 1 in every 10 does not have any access to the income they earn. The statistics indicate that lone mothers and older women (65+) living alone are the most vulnerable to poverty. Globally, only $47 \%$ of women had access to financial institutions and held an individual or joint account in banks compared to $55 \%$ men. Also, $28 \%$ of women are deprived of their inheritance rights owing to the absence of statutory laws whereas $52 \%$ of women do not have any access to inherited assets owing to discriminatory practices, even though the law mandates equal rights to men and women. In many countries, gender-based statistics on poverty does not exist making it difficult to estimate 
the real situation. In-depth analysis of these statistics point towards the lack of education as one of the main cause. Globally, two third of the 796 million people who can not read or write are women (UNDP, 2010) and only $54.5 \%$ of women have at least some secondary education (UNDP, 2015). This leads to lack of skills to fetch any opportunity for job and sometimes frustration. Another attribute of poverty among women is that they lack a political voice. As per the estimates only $21.8 \%$ of the global parliamentary seats are occupied by women, and only 38 countries have more than $30 \%$ women representation at the political level (UNDP, 2014).

\subsection{Tourism and Gender- Reportage}

As per the 1948 Universal Declaration of Human Rights, every person is equal before the law and is entitled to enjoy the human rights and fundamental freedom "without distinction of any kind such as race or sex". Gender equality is an imperial element in achieving economic, social and sustainable development for any country (Harris, 2000). Though gender equality consists of the development of both men and women equally, majority of the works focus mostly on women empowerment (Ferguson, 2010). Ensuring the rights of women has been a major dimension in global development and international policy documents. As a result, the Millennium Development Goals outlines Gender equality as its fifth goal and also many other goals directly or indirectly relate to women in development (UN, 2015b).

Tourism is a prime generator for jobs providing 3.6\% of the world's direct employment and $9.6 \%$ of the total (direct, indirect and induced) employment by 2014 (World Travel \& Tourism Council, 2015). Tourism, as an industry that supports leisure travel, is constituted by human relations and hence it affects as well as gets affected by local and global gender relations (Swain, 1995). In general terms, Tourism affects both men and women equally (Swain, 1990). However, tourism has shown tremendous potential for eradicating gender-related problems and therefore, has been quoted as a "vehicle for gender equality and women empowerment" (UN, 2011).

The tourism industry is characterized by low entry level barriers (Hollick, 2003) and high employment multiplier-effect (Frechtling 
\& Horvath, 1999). Because of these characteristics, tourism is believed to employ more women and minority groups. It is estimated that $60-70 \%$ of the total employment provided by tourism are occupied by women (International Labour Organisation, 2008). Also, tourism is mostly carried out as a parttime or shift based work in most parts of the world. Hence, women with household responsibilities can manage to earn part of their livelihood by engaging in these jobs in their leisure hours. Scheyvens (2000) argues that women are more connected to the environment than men owing to their continuous interactions with nature while collecting wood, drawing water or planting trees inthehome premises. She asserts that development of ecotourism destinations can be better carried out by women than men. Lama (2000) states that tourism generates jobs such as guiding, providing accommodation and food; those which can very well be carried out by female folk than male folk. He further argues that by interacting with tourists, women develop their formal and informal communication skills which in turn builds confidence and empowers them psychologically.

UNWTO, the apex body of World Tourism advocates gender equality and christened the World Tourism Day, 2005 celebration theme as 'Tourism Opens Doors for Women', following which it organized a forum on "Women in Tourism" at the tourism fair in ITB, Berlin, in the year 2008. The secretary of UNWTO, Taleb Rifai also quoted "Tourism sector can do more to step it up on gender equality" (UNWTO, 2015). All these facts reinforce that tourism can contribute immensely when it comes to empowering women and ensuring gender equality.

\subsection{The Dynamics of Tourism vis-à-vis Poverty Eradication Mechanism}

Tourism has been considered as a universal solution to inequity, poverty and to a certain extent conflict (IIPT, 2004). Being considered as a labour-intensive informal sector tourism endorses gender equality through women empowerment working on the assets of the poor (Ashley \& Roe, 2002). It has been depicted as a catalyst to the process of modernisation and an industry that fosters prosperity and economic growth especially for the poor 
nations (William, 1998). Tourism works on the fundamental principle of job and income multiplier, i.e. tourism not only generates income and jobs in the tertiary sector but also promotes both in the primary and secondary sector (Barcelona Field Studies Centre, n.d.). Another peculiarity of the Tourism sector is that each unit of capital spent in the tourism sector generates morenumber of jobs than any other industry in the world (Lickorish \& Jenkins, 1997).

Jafari's (2001) work on the advocacy approach of tourism highlights the potential of tourism to influence poverty at the micro or individual level. He states that tourism exposes the poor segment of people to a whole new 'modern' way of life. At the macro level, tourism has shown substantial growth in Least Developed Countries (LDCs). The industry showed massive progress in international tourist receipts from a mere US\$ 6.8 billion beginning in the 1960s to US\$ 941 billion by 2008 before falling to US\$ 852 billion in 2009. The share of some African countries in terms of tourism receipts showed threefold increase (Saner, Yiu \& Filadoro, 2015). Tourism is either the first or second best source of foreign exchange earnings in 20 out of the 48 LDCs and generates over $25 \%$ of the total GDPs in many developing nations notably small island nations (UNWTO). It is estimated that by 2030, developing economies like Asia, Middle East, Africa, etc. will receive $58 \%$ of international tourist arrivals (UNWTO, 2011).

Since the formulation of MDGs, Poverty eradication became the most common goal for the united world and tourism, as one of the fastest growing industries (Mowforth \& Munt, 1998; Goodwin 2000) as well as an integral component of economic growth in the developing nations (Harrison, 1992) galvanized its efforts to endorse the goal to eradicate poverty and even stated that an upward manoeuvrer of tourism would act as a 'war on poverty' (WTO, 2005). Dann (2002) in his works on developmental studies speaks highly about tourism and quoted tourism as a 'passport to development'. 


\section{The Slants of Tourism Advancements for Women Empowerment and Poverty Alleviation - an Analysis of Model Initiatives}

The previous section of this work aimed at establishing the vital connect between tourism, poverty alleviation and gender inequality. This part categorically presents the pragmatic perspectives of the linkages between the three as prevalent in the field i.e. the significant models which are vogue across the globe.

The case study approach has been adopted to unveil the ramifications of tourism activities as regards eradicating poverty mainly through equipping women professionals through a host of factors which includes skill development, functional training in industries such as handicrafts, cottage, textiles etc and others.

\subsection{Case Study I (Women Participation in Handicraft Making in Himachal Pradesh)}

"Unforgettable" is how the hilly state of Himachal Pradesh is promoted. The state with several fascinating tourists spot such as Kullu, Manali and Shimla are a frontrunner in India with regard to provision of souvenir articles for tourists. Women are known to play an active role in making exquisite handicraft items namely Kullu Shawls, Pashmina Shawls, unique costumes crafted with dexterity and aesthetics, wooden fabrics, blankets, lois, pattus, and patties. Women find handicrafts' design and making as having profound impact on the economy as an alternative source of livelihood. When the hilly farming areas do not yield much the people used to be in distress. Now, a with lot of refreshing avenues for producing articles, hand woven and others in vogue, the revenue generated to the local economy has increased a great deal. Women display artistic skills which are honed to much desired effects in making handlooms. The quality, texture and perfection of articles like shawls allure tourists. Moreover, the cold climatic conditions also trigger the purchase of shawls. The masterpiece artifacts are in huge demand and the people of the state, especially to better the production, form Self Help Groups (SHG). The traditional know-how is of course the base for the production of all artifacts. The State Government alsoprovides ample thrust through various initiatives to empower women in the souvenir industry. 
The products are displayed during the Kullu Dusshera, the Minoj Fair, the Winter Carnival, the Lavi Fair, and several other village fairs.

\subsection{Case Study II (Community based Tourism for Poverty Alleviation in Turkey)}

Women play a crucial role in designing and producing souvenir artifacts and other handicrafts ideally supported by the United Nations Development Programme (UNDP). The Ministry of Culture also actively involves in Sustainable tourism management and gives emphasis to the role of women in tourism development. Both the agencies collaborate to empower women socioeconomically by making them service providers in tourism which result in poverty alleviation (Tucker, 2007).

\subsection{Case Study III (The Ecotourism programme in Savannakhet Province in Laos)}

Women are encouraged to pro-actively participate in tourism ventures and the main enabler comprises of skill development and imparting education with the aim of accenting economic benefits from tourism. The local authority has given consultative status to women so as to ensure their dynamic participation and empowerment as well. Women do the roles of eco-guides, craft makers, cooks, homestay facilitators and cultural organizers. They enroll in various capacity building programmes including improvement of communication proficiency. Furthermore, women also strive fervently for the conservation of forest and wildlife in the area. The ecotourism project is partnership between SNV, which is a Netherlands Development Organisation and the United Nations Volunteers in Laos. The project advocates equality and empowerment at the educational level. Gender awareness workshops are a stark aspect of the project that focuses on sensitizing the stakeholders on the calibre of women in contributing positively to the success of initiatives. Women maintain rights to manage the money and possess control over the food supplies for ecotourists (Stoer, 2005). 


\subsection{Case Study IV (Metamorphosis of Women from Sex Tourism to souvenir and Craft Makers in Cambodia)}

Cambodia Tourism has a negative tag owing to prostitution and sex tourism. A Cambodian NGO by the name 'Acting for Women in Distressing Situations' (AFESIP) based in Phnom Penh rehabilitates victims of sex tourism and they are reintegrated into the societies. The former sex workers post-rescue are offered specialized training in craft making and scarf designing. The women folk are also given adequate opportunities to improve their language skills and for this courses are also conducted. Vocational training programmes are delivered by AFESIP to equip women with expertise to manage small businesses (AFESIP Cambodia).

\subsection{Case Study V (Women -Run Business Enterprises in Mukono} Parish, Uganda)

Of late, tourism has been spruced up in Mukono Parish lacated in Kanugu District in South Western Uganda. The ethnic Bakiga community is found to be more in place juxtaposed by the Bwindi National Park, a UNESCO World Heritage Site famous for Gorilla tracking ecotourism. The livelihood opportunities were very limited in the area before the advent of tourism. Mukono was in the grip of poverty as the people depended heavily on subsistence farming. Tourism emerged as an engine for local economic growth and gave fillip to the inception of schools, pure drinking water facilities and health centers. Women in the area, for the first time found employment opportunities in Buhoma Community Rest Camp initiative, Community Walk initiative and the Bwindi Advanced Market Gardeners' Association Vegetable initiative. Further, they performed native cultural expressions and they run handicraft enterprises. The profits from these ventures are channelized towards laying roads and developing other infrastructural facilities. Women supplied food and beverages to tourists in the rest camps. The community walk initiatives configured 10 stopping sites among which women operated craft shops and several indigenous facets of the place they showcased lured tourists. The expertise of many women in weaving baskets are tapped to a great effect in generating revenue (Boonabaana, 2014 \& Lydia, 2010). 


\section{Inferences and Discussions}

The reviews and analyses of academic literature have underscored the fact that sources of NGO's are emerging across the world that focus on women empowerment in various spheres like health, agriculture, micro finance, etc. Though, women empowerment in tourism is at the formative stage, it has created a mark as the mainstay of community participation. The zealous activities of women in tourism; particularly in developing countries have resulted in the betterment of many an economically marginalized region. The analytical output categorically points out that women led tourism initiatives promotes the sustainable use of natural resources and strengths the control over planning and development of the areas.

The process of women participation in tourism projects and endeavours are found to add teeth to equitable and sustainable development. Furthermore, it has been brought to light that if adequate exposure is given, coupled with technical support for skills' development, the benefits from tourism could be harnessed more pronouncedly culminating in increased socio-economic development in the tourism zones. Other favorable aspects which can intensify the role of women in tourism and thereby reduce poverty are conducive micro and macro environment forces, encouraging policy initiatives, support of Governments and hasslefree allocation of financial incentives.

Empowering women have deeper implications towards addressing many ills that have affected the societies as revealed by the case studies analyzed in the study. Furthermore, women are found to be more sensitive to involve vigorously and meticulously in the preservation and maintenance of cultural manifestations and natural resources.

Thus, it can be inferred concretely that the more the number of avenues are created in the sphere of tourism for the pro-active involvement of women, the more stable and enticing would be the tourism business at the global level. 


\section{Conclusion}

This work analysed the manifold impacts of women empowerment in tourism. The most significant impact certainly was the enamouring effects on the proposition of alleviating poverty especially in rural destinations. Consequently, more destinations from all over the world are tuning into the idea of involving women in tourism projects, mainly the community-run enterprises. Ardent efforts are in full swing to equip the women folk in destinations with appropriate skills. Several capacity building programmes in this line have been underscored in the case study part of this work. Furthermore, it is observed that the advantages of women empowerment in tourism also go a long way in mitigating the challenges related to gender bias and inequality. Women operated tourism ventures are found to work in sync with conservation of natural resources and alleviating poverty.

\section{References}

AFESIP Cambodia. Retrieved October 26, 2016, from http://www.afesip.org/

Ashley, C. \& Roe, D. (2002). Making tourism work for the poor: Strategies and challenges in southern Africa. Development Southern Africa 19 (1), 61-82.

Assembly, U. G. (1948). Universal declaration of human rights. UN General Assembly.

Barcelona Field Studies Centre. Tourism Multiplier Effect. Geographyfieldwork.com.Retrieved September 21, 2016, from http://geographyfieldwork.com/TouristMultiplier.html

BBC-Poverty-Definitions. (2016). Bbc.co.uk. Retrieved September 11, 2016, from http: // www.bbc.co.uk / Scotland / education / ms / wealth / def_of_poverty / definitions.shtml.

Boonabaana, B. (2014). Negotiating gender and tourism work: Women's lived experiences in Uganda. Tourism and Hospitality Research, 14(1-2), 27-36.

Cagatay, N. (1998). Gender and poverty. UNDP, Social Development and Poverty Elimination Division.

Chant, S. (2007). Gender, generation and poverty. Cheltenham: Edward Elgar. 
Ferguson, L. (2010). Interrogating 'gender'in development policy and practice: The World Bank, tourism and microenterprise in Honduras. International Feminist Journal of Politics, 12(1), 3-24.

Foster, J. E., \& Sen, A. (1997). On economic inequality. Expanded edition.

Frechtling, D. C., \& Horvath, E. (1999). Estimating the multiplier effects of tourism expenditures on a local economy through a regional inputoutput model. Journal of travel research, 37(4), 324-332.

Goodwin, C. (2000). Action and embodiment within situated human interaction. Journal of pragmatics, 32(10), 1489-1522.

Gordon, D. (2005). Indicators of Poverty \& Hunger. Expert Group meeting on youth development indicators (pp. 12-14).

Harris, J. M. (2000). Basic principles of sustainable development. Medford, MA: Tufts University.

Harrison, D. (1992). Tourism and the less developed countries. Belhaven Press.

Hollick, M. (2003). No barriers to failure: rethinking tourism business entry. CAUTHE 2003: Riding the Wave of Tourism and Hospitality Research, 562.

International Institute for Peace Through Tourism (IIPT) (2004) January Newsletter. Retrieved December 12, 2016, from http:/ /www.iipt.org/ newsletter/ January2004.html

International Labour Organisation. (2008). Gender. Retrieved September 10, 2016, from http://www.ilo.org/ wcmsp5/ groups/ public/ ed_dialogue/sector/documents/briefingnote/wcms_162188.pdf

Jafari, J. (2001). The scientification of tourism. In V.L. Smith and M. Brent (eds) Hosts and Guests Revisited: Tourism Issues of the 21st Century (pp. 28-41). New York: Cognizant Communication.

Lama, W. B. (2000). Community-based tourism for conservation and women's development. Tourism and development in mountain regions, 221-238.

Lipton, M., \& Ravallion, M. (1995). Poverty and policy. Handbook of development economics, 3, 2551-2657.

Lydia, N. (2010). Community Leadership and Poverty Reduction in Uganda: The Peap in Mukono District. (Published Thesis, Master of Arts Degree in Leadership and Human Relations Studies). Makerere University, Uganda.

McArthur, J. W. (2014). The origins of the millennium development goals. SAIS Review of International Affairs, 34(2), 5-24.

Mowforth, M., \& Munt, I. (1998). Tourism and sustainability: New tourism in the third world. New York. Oxford Dictionaries. Retrieved October 15, 2016, from http://www.oxforddictionaries.com/ definition/ english/poverty 
Pearce, D. (1978). The Feminization of Poverty: Women. Work.

Saner, R., Yiu, L., \& Filadoro, M. (2015). Tourism Development in Least Developed Countries: Challenges and Opportunities. Handbook of Research on Global Hospitality and Tourism Management, 229.

Scheyvens, R. (2000). Promoting women's empowerment through involvement in ecotourism: Experiences from the Third World. Journal of sustainable tourism, 8(3), 232-249.

Scheyvens, R. (2008). Current Issues in Tourism Exploring the TourismPoverty Nexus Exploring the Tourism-Poverty Nexus. Current Issues in Tourism, 37-41.

Sen, A. (1997). Resources, values, and development. Harvard University Press.

Singh, S. (2007). Deconstructing "gender and development for identities of women". International Journal of Social Welfare, 16, 100-109.

Skeat, W. (1980). A Concise Etymological Dictionary of the English Language. Perigee Books.

Stoer, P. (2005). Ecotourism development in Laos. Presentation, Workshop R'dam School of Management.

Swain, M. (1995). Gender in tourism. Annals of Tourism Research, 22(2), 247266.Retrieved October 08, 2016, from http:/ / dx.doi.org/10.1016/01607383(94)00095-6

Swain, M. B., \& Smith, V. L. (1989). Gender roles in indigenous tourism: Kuna Mola, Kuna Yola, and cultural survival. Hosts and guests. The anthropology of tourism, (Ed. 2), 83-104.

Tucker, H. (2007). Undoing shame: Tourism and women's work in Turkey. Journal of Tourism and Cultural change, 5(2), 87-105.

UN. (2011). Tourism a vehicle for gender equality and women's empowerment, UN reports | Regional Programme for Europe. Europe.unwto.org.

Retrieved September 19, 2016, from http:/ / europe.unwto.org/ news/ 2011-03-11/tourism-vehicle-gender-equality-and-women-sempowerment-un-reports

UN. (2015). The World's Women 2015 (pp. 179-199).Retrieved November 11, 2016,http://unstats.un.org/unsd/gender/downloads/WorldsWome n 2015 _chapter8_t.pdf

UNDP. (2010). Empowering women through literacy empowers us all. Retrieved September 20, 2016, from http://www.undp.org/content/ undp/ en/ home/ presscenter/articles/2010/09/08/empoweringwomen-through-literacy-empowers-us-all.html

UNDP. (2014). Human Development Reports - Table 5: Gender Inequality Index. Hdr.undp.org. Retrieved September 22, 2016, from http:// hdr.undp.org/en/composite/GII\#c 
UNDP. (2016). Gender Inequality Index (GII) | Human Development Reports. Hdr.undp.org.Retrieved September 11, 2016, from http:// hdr.undp.org/en/content/gender-inequality-index-gii

United Nations. (2015b). The Millennium Development Goals Report. United Nations. Retrieved November 04, 2016, from https://visit.un.org/millenniumgoals/2008highlevel/pdf/ MDG_ Report_2008_Addendum.pdf

UNWTO. (2011). International tourists to hit 1.8 billion by 2030. Retrieved December 11, 2016, from http://media.unwto.org/en/pressrelease/2011-10-11/international-tourists-hit-18-billion-2030

UNWTO. (2013). Tourism and Poverty Alleviation | Tourism and Poverty Alleviation. Step.unwto.org. Retrieved September 21, 2016, from http:// step.unwto.org/content/tourism-and-poverty-alleviation-1

Whitehead, A. (2003). Failing women, sustaining poverty: Gender in poverty reduction strategy papers: Report for the UK Gender and Development Network. Oxford: Oxfam GB.

Williams, S. (1998). Tourism Geography. London: Routledge.

World Bank. (2013). Poverty Overview. Worldbank.org. Retrieved September 11, 2016, from http:// www.worldbank.org/ en/ topic/ poverty/overview

World Tourism Organization (WTO) (2005) 'Use tourism on war on poverty' world leaders urged. Retrieved January 01, 2017, from http://www.asiatraveltips.com/news05/159-Tourism.shtml

World Travel \& Tourism Council. (2015). Economic Impacts 2015 (pp. 1-5). London. Retrieved October 26, 2016, from https://www.wttc.org// media/files/reports/economic\%20impact\%20research/regional \% 202015/world2015.pdf

Zuckerman, E. (2001). Engendering Poverty Reduction Strategy Papers (PRSPs). Why it Reduces Poverty and the Rwanda Case. In WIDER Development Conference on Debt Relief. 